\title{
GROWTH, YIELD AND POSTHARVEST QUALITY OF WAX APPLE AS AFFECTED BY NAPHTHALENE ACETIC ACID APPLICATION ${ }^{1}$
}

\author{
MOHAMMAD MONERUZZAMAN KHANDAKER ${ }^{2 *}$, ABM SHARIF HOSSAIN ${ }^{3}$, \\ NORMANIZA OSMAN ${ }^{4}$, NASHRIYAH MAT ${ }^{2}$, AMRU NASRULHAQ BOYCE $^{4}$
}

\begin{abstract}
Results of this study represent the first report of the effect of Naphthalene Acetic Acid (NAA) on the pre and post harvest quality of wax apple fruit. The wax apple trees were spray treated with $0,5,10$ and $20 \mathrm{mg} \mathrm{L}^{-1}$ NAA under field conditions during 2008 to 2011. The experiments were carried out in Completely Randomized Design (CRD) with six replications. Leaf chlorophyll content, chlorophyll fluorescence, photosynthetic yield, net photosynthetic rate, drymatter content of leaves and total soluble solids and $\mathrm{K}^{+}$ content of wax apple fruits were significantly increased after treatments with $10 \mathrm{mg} \mathrm{L}^{-1}$. Polygalacturonase activity significantly decreased with NAA treatments. The application of $5 \mathrm{mg} \mathrm{L}^{-1} \mathrm{NAA}$ increased $27 \%$ more bud and reduced $42 \%$ less fruit drop compared to the control. In addition, higher protein and phosphate synthase activity of leaves, fruit set, fruit growth, larger fruit size and yield were recorded in NAA treated plants. In storage, treated fruits exhibited higher TSS and firmness and less weight loss, browning, titratable acidity, respiration and ethylene production than the control. It is concluded that spraying with 5 and $10 \mathrm{mg}$ $\mathrm{L}^{-1}$ NAA once a week under field conditions produced better fruit growth and yield of the wax apple and maintained better fruit quality in postharvest storage.
\end{abstract}

Index terms: NAA, fruit, development, pre and postharvest quality.

\section{CRESCIMENTO, RENDIMENTO E QUALIDADE NA PÓS COLHEITA DE CERA DE MAÇÃ EM FUNÇÃO DA APLICAÇÃO DE NAFTALENOACÉTICO}

RESUMO-Os resultados deste estudo representam o primeiro relatório do efeito do ácido naftalenoacético (NAA) sobre a qualidade da colheita de pré e pós de frutas de cera de maçã. As árvores de cera de maçã foram tratadas com spray de $0 ; 5 ; 10$ e $20 \mathrm{mg} \mathrm{L}^{-1}$ NAA em condições de campo, durante 2008 a 2011. Os experimentos foram conduzidos em delineamento inteiramente casualizado (DIC), com seis repetições. Folha, teor de clorofila, fluorescência da clorofila, o rendimento fotossintético, a taxa de fotossíntese líquida, o teor da matéria seca das folhas e sólidos solúveis totais e $\mathrm{K}+$ conteúdo da maçã de cera aumentaram significativamente após os tratamentos com $10 \mathrm{mg} \mathrm{L}^{-1}$. Atividade Poligalacturonase diminuiu significativamente com tratamentos NAA. A aplicação de $5 \mathrm{mg} \mathrm{L}^{-1}$ NAA aumentou em $27 \%$ os brotos e reduziu $42 \%$ a queda de frutos em comparação com o controle. Além disso, mais proteína e atividade fosfato sintase de folhas, frutificação, crescimento do fruto, maior tamanho do fruto e rendimento foram registrados nas NAAs, nas plantas tratadas. No armazenamento, os frutos tratados apresentaram maior TSS e firmeza, e menos perda de peso, escurecimento, acidez titulável, respiração e produção de etileno em relação ao controle. Conclui-se que a pulverização com 5 e $10 \mathrm{mg} \mathrm{L}^{-1} \mathrm{NAA}$ uma vez por semana, em condições de campo, produziu melhor crescimento do fruto a produção da maçã cera e mantendo melhor qualidade dos frutos na conservação pós-colheita.

Termos para indexação: NAA, fruta, desenvolvimento, qualidade pré e pós-colheita.

\footnotetext{
${ }^{1}$ (Trabalho 062-14). Recebido em: 13-02-2014. Aceito para publicaçaõ em: 01-04-2015.

${ }^{2}$ School of Agriculture Science and Biotechnology,Faculty of Bioresource and Food Industry, University of Sultan Zainal Abidin,Tembila Campus, 22200 Besut,Terengganu, Malaysia.E-mails: moneruzzaman@unisza.edu.my ;nashriyah@unisza.edu.my

${ }^{3}$ Biotechnology Program, Biological Sciences, Faculty of Science, University of Hail ,Hail, KSA. E-mail: abm.hossain@uoh.edu.sa ${ }^{4}$ Institute of Biological Sciences , Faculty of Science, University of Malaya , 50603 Kuala Lumpur, Malaysia. E-mail: normaniza@ um.edu.my, amru@um.edu.my
} 


\section{INTRODUCTION}

The wax apple is a nonclimacteric tropical fruit tree from the Myrtaceae family with its origin in the Malay Archipelago and botanically identified as Syzygium samarangense (MORTON, 1987). Wax apple is widely cultivated throughout Malaysia, mainly as smallholdings ranging from 1 to $5 \mathrm{ha}$, with a total hectarage estimated at 1500 ha in 2005 . The production area and production for the year 2003 in Indonesia were 13,454 ha and 239,108 tons, in Taiwan were 7,302 ha, 84,991 tons (ZEN-HONG et al., 2006). The ripe, pink fruits of wax apple are bell-shaped, sweet and can be eaten fresh or cooked, for sauces, jams, jellies desserts, wines, liquors, and vinegars. The fruits of apple air are eaten raw with salt or cooked as a sauce. Ninety per cent or more of the fruit is edible. The fruits can be used for several inflammatory conditions, including sore throat, high blood pressure, and as an antimicrobial, antiscorbutic, carminative, diuretic, and astringent (KHANDAKER et al., 2011). It has become an increasingly popular fruit in the tropical region where it can fetch a price of up to 3USD per kilogramme and has the potential to bring great benefits to local farmers and the country's economy (KHANDAKER et al., 2012a; MONERUZZAMAN et al., 2012).

It is important for fruit growers to have information on the differences in fruit quality among the available fruit varieties and the changes occurring in fruit quality parameters over time. PGRs enhance the rapid changes in physiological and biochemical characters and improve crop productivity. The application of $\mathrm{GA}_{3}$ at $20 \mathrm{mg} \mathrm{L}^{-1}$ associated with CPPU at $10 \mathrm{mg} \mathrm{L}^{-1}$ improved berry size of Italia grapes without affecting cluster mass, leading to higher grape quality (RODRIGUES et al. 2011). It has been reported that application of NAA before flowering, followed by three weeks after fruit set significantly increased fruit length, diameter and fruit weight as well as yield in guava (DUTTA; BANIK, 2007; ALMESELMANI, et al., 2010).

Auxins have been reported to effective in enhancing fruit growth, when applied during the second stage of fruit development in tomato (SERRANI et al. 2008). These auxins are known for their ability to increase cell enlargement thus enhancing fruit growth in citrus (AUGUSTI et al., 1995). NAA has been shown to significantly increase fruit yield, total soluble solids (TSSs), total sugar content, fruit color in Bing cherry, and vitamin C in guava fruits (IQBAL et al., 2009). The postharvest losses may depend on external and internal conditions, which affect the fruit firmness, juice content, weight loss, $\mathrm{pH}$, soluble solids content (SSC), and other quality parameters (TU et al., 2000). FIGUEROA et al. (2012) reported that calcium and auxin alter fruit ripening preventing the normal degradation of cell wall during cold storage. They also found that NAA treatments had no significant affect on firmness, acidity, and soluble solids content (SSC) of strawberry in cold storage.

Currently, no information is available in the literature on the effects of NAA on wax apple fruit growth, yield and postharvest quality. Hence, this study is aimed to evaluate the effects of NAA on fruit growth, yield and quality of wax apple under field conditions. It is proposed that the application of NAA can affect or promote the pre and postharvest quality of the wax apple fruit.

\section{MATERIALS AND METHODS}

The present study were carried out in an orchard located at MARDI, Klang and a commercial farm in Banting, $2^{\circ} 30 \mathrm{~N}, 112^{\circ} 30 \mathrm{E}$ and $1^{\circ} 28 \mathrm{~N}, 111^{\circ}$ $20 \mathrm{E}$ at an elevation of about 45 meter from sea level. The area under study has a hot and humid tropical climate. The soil in the both orchard is peat with a mean $\mathrm{pH}$ of around 4.6 (KHANDAKER et al., 2013). Experiments were conducted between 2008 to 2011. The first season (December 2008 to April 2009) of the experiments was performed at MARDI, Jalan Kebun, Klang, and the second (May 2009 to October 2010) and third (December 2010 to May 2011) seasons' experiments were conducted at the farm in Banting.

Twelve years old wax apple trees were selected for the study. The trees were planted at $4.2 \mathrm{~m} \times 4.2 \mathrm{~m}$ in hexagonal system and received the same horticultural management. Twenty four trees were used in the experiment for each season. One hundred twenty uniform branches (five branches per tree) of the same length, and diameter, and approximately same number of leaves were selected for the experiments. The experiment consisted of four treatments including the control, in six replicates and a single tree was taken as an experimental unit. The selected uniformed branches were sprayed with 5, 10 and $20 \mathrm{mg} \mathrm{L}^{-1} \mathrm{NAA}$ and water (control) each once a week at the beginning of flower opening through fruit development. The experiments were arranged on the selected branches in a completely randomized design (CRD). A total of six spraying times were carried out; two times before anthesis and four times after anthesis and $350 \mathrm{ml}$ NAA solution was used per treatment (thirty branches). For postharvest storage, all the harvested fruits were kept at $8 \pm 2^{\circ} \mathrm{C}$ and 85 to $90 \%$ relative humidity during 2010 and 2011 seasons. In storage, 
completely randomized design (CRD) with three replications was used. Two $\mathrm{kg}$ of uniformed size wax apple fruits was kept in each replication. The data on the postharvest quality parameters were carried for 4 days, on days $0,5,10$ and 15 during storage periods. Total chlorophyll content (SPAD value) in the leaves of the plant was recorded using SPAD meter (Konica-Minolta Model 502). Chlorophyll fluorescence was measured by Hansatech Plant Efficiency Analyzer (PEA). It was represented by lower fluorescence (F0), higher fluorescence (Fm) and relative variable fluorescence $(\mathrm{Fv})$. Optimum quantum yield $(\mathrm{Fv} / \mathrm{Fm})$ also evaluated at $28^{\circ} \mathrm{C}$ and time range was $10 \mu \mathrm{s}-3 \mathrm{sec}$. Stomatal conductance was measured by a portable Leaf Porometer (Model SC-1, USA). Leaf dry matter was measured at $0 \%$ moisture. The photosynthetic rate $(\mathrm{Pn})$ was measured using a portable photosynthesis system (Li-6400XT, Li-COR, USA) and measurements were carried out according to methods of KHANDAKER et al. (2012a). The desalted crude extract preparation for enzyme analysis and protein content were determined according to the method described in KHANDAKER et al. (2012a) using bovine serum albumin as standard. SPS activity was assayed under Vmax conditions as described in KHANDAKER et al. (2012a). The methodology to measure total polygalacturonase (PG) activity was adapted from LU; LAN (2011). PG activity of fruit juice was assayed spectrophotometrically and absorbance was measured with a UV spectrophotometer at $276 \mathrm{~nm}$, using $\alpha$-D-galacturonic acid as a standard (GROSS, 1982). For determination of respiration and ethylene production rate $1 \mathrm{~kg}$ fruits were kept on a sealed plastic jar for 1 hour in storage condition. Carbon dioxide and ethylene concentration of wax apple fruits were determined with a Shimadzu GC-8A gas chromatograph (Tokyo, Japan), equipped with Porapak Q 80/100 column and flame ionization detector. The respiration and ethylene production rates were calculated and expressed as $\mathrm{mg} \mathrm{CO} \mathrm{kg}^{-1}$ $\mathrm{h}^{-1}$ and $\mathrm{nL} \mathrm{kg}^{-1} \mathrm{~h}^{-1}$.

Total number of buds, fruit growth (length and diameter) fruit set, fruit drop, yield and fruit dry matter were measured according to KHANDAKER et al. (2012a). The surface color of each tagged fruit was determined at three different points of the fruit using a standard color chart (Minolta, Osaka, Japan) and expressed as percentage of color cover. $\mathrm{K}^{+}$content of fruit juice was determined by using a Cardy Potassium meter (Horiba C-131). Total soluble solids (TSS) was evaluated at $25^{\circ} \mathrm{C}$ with an Atago 8469 hand refractometer (Atago Co. LTD., Tokyo, Japan) and expressed as ${ }^{\circ}$ Brix. Fruit firmness was determined with a digital hand-held penetrometer (Model KM-1, Fujiwara, Japan). The weight loss of jambu air fruit samples were calculated by differences between initial weight and final weight divided by initial weight (KHANDAKER et al., 2009). The weight loss of the same sample was recorded periodically during the storage period. The $\mathrm{pH}$ of the wax apple juice was recorded using a pH meter (Hanna $\mathrm{pH} 211$, Italy). The fruit juice $(10 \mathrm{~mL})$ was titrated with $0.1 \mathrm{M} \mathrm{NaOH}$, and the results are expressed in terms of percentage citric acid. The percentage of citric acid was calculated using the formula of BHATTARAI; GAUTAM (2006). Browning index was estimated according to the methods described by SUPAPVANICH et al. (2011). The result was expressed as the mean of the four replication of the absorbance.

The experimental design was a completely randomized design (CRD) with six replications. The data obtained from the three seasons were pooled and analyzed using MSTAT statistical software. One way ANOVA was applied to evaluate the significant difference in the parameters studied in the different treatments. The least significant difference (Fisher's protected LSD) was calculated, following a significant F-test $(\mathrm{p}=0.05)$.

\section{RESULTS}

The chlorophyll content, which can indirectly indicate the health status of a plant, determined using a Minolta SPAD meter, was significantly $(p<0.05)$ higher in the leaves of NAA-treated branches (Table 1). The chlorophyll content in leaves from all the treated branches were higher than the control branch, up to $33 \%$ higher, in the $10 \mathrm{mg} \mathrm{L}^{-1}$ treated branch branches. NAA treatments had a significant effect on chlorophyll fluorescence of wax apple leaves (Table 1). The highest maximum fluorescence (Fm) was observed in $10 \mathrm{mg} \mathrm{L}^{-1} \mathrm{NAA}$ treatment, followed by 5 and $20 \mathrm{mg} \mathrm{L}^{-1} \mathrm{NAA}$ treatments respectively, whereas, the lowest (F0) value was recorded in the leaves of the control branches. Ground state fluorescence $\left(\mathrm{F}_{0}\right)$ and variable fluorescence $(\mathrm{Fv})$ was higher in $20 \mathrm{mg} \mathrm{L}^{-1}$ treatment followed by 10 and 5 $\mathrm{mg} \mathrm{L}^{-1}$ NAA treatments respectively, whilst, leaves of control branches produced the lowest fluorescence $\left(\mathrm{F}_{0}\right)$. With regard to quantum yield, NAA treatments also showed a significant effect (Table 1). Our results showed that NAA had a significant effect on stomatal conductance and dry matter content in treated leaves (Table 1).

Results show that NAA treatments increased the leaf photosynthetic activity considerably. The 
activities were 1.5-, 2.36- and 1.96-fold higher than the control at $350 \mathrm{ppm} \mathrm{CO}_{2}$ and light intensities of 400, 800 and $2000 \mathrm{mmol} \mathrm{m}^{-2} \mathrm{~s}^{-1}$, respectively, in the leaves treated with $10 \mathrm{mg} \mathrm{L}^{-1}$ NAA (Figure 1). Leaf photosynthesis was the highest with the 10 $\mathrm{mg} \mathrm{L}^{-1}$ treatment, followed by the 5 and $20 \mathrm{mg} \mathrm{L}^{-1}$ treatments, in that order, whereas the control leaves evidenced the least photosynthesis. The results show that NAA treatments increased the leaf SPS activity of wax apple plants (Table 2). Table 2 shows that NAA treatments did not produced significant effect on leaf soluble protein among themselves, although, it was significantly different between the treatments and control. NAA produced a significant effect on bud number and fruit set of wax apple (Table 2). Results show that $5 \mathrm{mg} \mathrm{L}^{-1}$ NAA-treated branch produced $26 \%$ higher bud than the control treatment. Fruit set was almost 1.74 fold in $20 \mathrm{mg}$ $\mathrm{L}^{-1}$ NAA-treated branches compared to those in the control (Table 2). The control branches produced the lowest fruit set.

The results showed that NAA-treated branches exhibited higher fruit growth rate from the first week till the $7^{\text {th }}$ week, with regard to fruit length and diameter (Figures 2 and 3 ). At the $3^{\text {rd }}$ week of observation, fruit length was $4.86 \mathrm{~cm}$ and $4.1 \mathrm{~cm}$ in 10 and $5 \mathrm{mg} \mathrm{L}^{-1}$ NAA treatments respectively, whereas, it was $3.4 \mathrm{~cm}$ for the control fruit. Similarly, the average fruit diameters at $2^{\text {nd }}$ week were 2.06 and $1.67 \mathrm{~cm}$ for the 10 and $5 \mathrm{mg} \mathrm{L}^{-1}$ NAA-treated fruits, whereas it was $1.16 \mathrm{~cm}$ in the control fruits. On the basis of these results, it can be seen that all the treated fruits grew at a faster rate and were larger than the untreated control fruits. Results revealed that fruit color development was greatly enhanced by the NAA treatments used in this study, with the 5 and $10 \mathrm{mg} \mathrm{L}^{-1} \mathrm{NAA}$ treated fruits exhibiting the greatest percentage color cover from day 14 till day 28 (Figure 4). Furthermore, it was observed that on 14 days after anthesis, the red color of the fruits had already started to show in the treated branches compared to the control fruits, which only started coloring one week later. At the $28^{\text {th }}$ day of observation, the 10 $\mathrm{mg} \mathrm{L}^{-1}$ treated fruits showed more or less $60 \%$ red color whereas, control was only $28 \%$ color covered.

In our experiment, we count the fruit number per treated branch separately in each season. NAA treatment had a significant effect on fruit number in all seasons. For the first season, our results showed that fruit number was 1.5 times higher in $5 \mathrm{mg} \mathrm{L}^{-1}$ NAA treatment compared to control (Figure 5). All the treated branches produced the highest number of fruits compared to the untreated branches. The same trends were also recorded in $2^{\text {nd }}$ and $3^{\text {rd }}$ season.
Regarding fruit drop, NAA treatments reduced fruit drop compared to control and their differences were statistically significant (Table 2). The results also showed that NAA treatments significantly reduced the polygalacturonase activity of wax apple fruits. The highest PG activity was recorded in dropped fruits compared to treatment groups (Figure 6). The results showed that the treated branches exhibited a higher yield of fruits compared to the control, which were found to be statistically significant between treatments and control. As shown in Table 2, all the treated branches in this study exhibited a higher yield compared to those in the untreated control. The yield, on a fruit weight basis was almost double in the fruits from the $10 \mathrm{mg} \mathrm{L}^{-1}$ treated branches compared to the control. As shown in Figure 7, we observed that fruit yield of $10 \mathrm{mg} \mathrm{L}^{-1}$ NAA treatments showed a strong co relationship $\left(\mathrm{R}^{2}=0.737\right)$ with stomatal conductance of leaves. Fruit yield $(\mathrm{kg})$ increased simultaneously with the stomatal conductance of leaves. NAA treatments resulted significant differences in the $\mathrm{K}^{+}$ content in treated and non-treated fruits (Table 2). Results showed that the $\mathrm{K}^{+}$content of fruit juice was the highest in $10 \mathrm{mg} \mathrm{L}^{-1}$ treated fruits followed by 5 and $20 \mathrm{mg} \mathrm{L}^{-1}$ NAA treated fruits, whereas control fruits produced the lowest value. NAA treated wax apple fruit quality attributes (firmness, weight, TA, $\mathrm{SSC}, \mathrm{pH}$ and browning index) were analyzed during storage at immediately after $3^{\text {rd }}$ season harvest (Table 3 ). Our results showed that the pulp firmness of wax apple fruits was significantly affected by NAA treatments. The highest $(7.8 \mathrm{~N})$ and the lowest $(7.0$ $\mathrm{N})$ pulp firmness were in $10 \mathrm{mg} \mathrm{L}^{-1} \mathrm{NAA}$-treated and untreated fruits. It was also observed that firmness of the treated fruit was reduced throughout the storage but the reduction rate was slower than the control (Table 3). Our results show that, the weight loss increased with storage period and NAA-treated fruits retained higher weight values than control fruit during storage (Table 3). After 15 days of storage a significant greater fruit weight was recorded in NAA-treated fruits than control treatment. As shown in Table 3, the highest TSS value of 10.7 $\left({ }^{\circ}\right.$ Brix) was observed in $10 \mathrm{mg} \mathrm{L}^{-1}$ NAA-treated fruit. The minimum TSS in the control samples was 6.70 ( ${ }^{\circ}$ Brix). In storage, values of TSS showed no significant differences between treatments (Table 3 ), although high values in TSS were recorded for NAA-treated fruits compared with control fruits.

After cold storage, values of titratable acid (TA) and $\mathrm{pH}$ showed significant differences between treatments and control (Table 3), although high value of TA found in the control fruits. The result showed that TA increased initially thereafter 
decrease throughout storage in both control and treated fruits. As can be seen in Table 3, the $\mathrm{pH}$ of the fruit juice throughout the experimental storage period was within the narrow range of $\mathrm{pH} 4.9-\mathrm{pH}$ 22. An increase in browning soluble pigment (the absorbance at $420 \mathrm{~nm}$ ) has shown a high browning susceptibility of wax apple flesh during storage. Flesh browning index is a key factor limiting quality of wax apple. It can be seen from the Table 3, NAA treatments significantly reduced the browning index of wax apple fruit.

The results also showed that NAA treatments significantly reduced the respiration rate and ethylene production of wax apple fruit in cold storage. The respiration rate was higher in control fruits compared to treated fruits. At the $10^{\text {th }}$ day of observation, ethylene production rate was 1.45 times higher in control fruits than the NAA treated fruits.

\section{DISCUSSION}

In this present study, leaf chlorophyll content of wax apple plants were significantly affected by NAA treatments. GUTAM, et al. (2009) also reported similar positive effects of NAA on chlorophyll content of Bell pepper. Synthetic auxin stimulated the chlorophyll synthesis as well as increased the chlorophyll fluorescence (CZERPAK et al., 2002). The results of this study also stated that NAA treatments improved the chlorophyll fluorescence as well as quantum yield of wax apple plants. Stomatal conductance affects the photosynthetic rate by regulating $\mathrm{CO}_{2}$ fixation in leaf mesophyll tissue and is positively correlated with photosynthesis. Foliar application of NAA significantly increased stomatal conductance of wax apple plants. These findings were found to be in agreement with that of NAHAR; TAKESHI, (2002) who observed that synthetic auxins increase the stomatal conductance in soybean. Our results for the changes in leaf dry matter are in agreement with the report of KOLER et al. (2008), who reported that $30 \mathrm{mg} \mathrm{L}^{-1}$ NAA significantly increased the leaf dry matter of hybrid cotton.

Net photosynthetic rate in wax apple leaves increased notably with doses of NAA. IERSEL (1999) also reported that synthetic auxin NAA increased the net photosynthesis rate, plant biomass and growth of Vinca seedlings. It was also observed that leaf protein content of treated plants increased with NAA application. Sucrose phosphate synthase, an enzyme important for the synthesis of sucrose in leaves was also affected by NAA treatment. The increased photosynthetic rate could possibly provided more fructose and glucose 6-phosphate which in turn stimulated sucrose synthesis via sucrose phosphate synthase activity. BHOWMIK, et al. (2006) also found positive relationships between SPS activity and sucrose accumulation in perennial ryegrass. PGRs treatments may also increase the invertage activity, the increase invertage activity suggests for sucrose synthesis and vice versa due to increased photosynthetic product in treated leaves. The increased SPS activity could raise not only sucrose level but also glucose and fructose level in leaves and fruits of wax apple. Similar results were reported by MAAIKE et al. (2009) in tomato fruits.

Our results reported that NAA treatments increased the bud number, fruit set and fruit growth of wax apple. MILLER et al. (1987) also reported that auxins level in the fruit can promote the sink potential of the fruits, which is in direct proportion of to the rate of fruit growth. During the cell enlargement period, synthetic auxin increases photosynthesis and carbohydrate availability causing cell enlargement and also increase in final fruit size (AGUSTI et al., 1995). Auxin may stimulate translocation of carbohydrate to the fruits and increased cell wall elasticity as well as induced fruit growth (SERRANI et al., 2008). The auxins and gibberellins are used to control the fruit drop in citrus and to improve the quality of fruit. Our results related to fruit drop showed a concurrence with the findings of DAVIES; ZALMAN (2006) who observed that synthetic auxin (NAA and 2,4-D) significantly reduce the fruit drop in citrus fruits.

Polygalacturonase degrades polysaccharides present in the cell walls of plants by hydrolysis of the glycosidic bonds and the major component of pectin. PG enzymes loosen the structure of mixed cutin with polysaccharides and stimulates fruit drop by hydrolysis the glycosidic bonds and the major components of pectin of abscission zone. In this study, it was observed that polygalacturonase activity in dropped fruit was higher compared to treated fruits. Consequently, NAA treatments significantly reduced the polygalacturonase activity and reduced the fruit of wax apple plants. NAA treatments significantly increased the peel color of wax apple fruits in this study, possibly because of an increment in the accumulation of pigment in the skin. Our findings are supported by the results of AGUSTI et al. (1995) who reported that synthetic auxin enhanced the fruit color development in loquat fruit. It has been reported earlier that, NAA affects the number of fruits per plant. Our results related to fruit retention were found to be consequence with that of AMOROS et al. (2003) who reported that $10 \mathrm{mg} \mathrm{L}^{-1}$ NAA treatment increased the total number fruits as well as yield in 
loquat. The results of this study showed that fruit yield were significantly higher in treated plants compared to untreated group. AMOROS et al. (2003) also reported similar positive effects of NAA on loquat fruit yield. Correlation between fruit yield and stomatal conductance of wax apple were supported by the findings of LU et al. (1998) who reported that yield had a positive correlation with stomatal conductance in Pima cotton and bread wheat.

Our results showed that $\mathrm{K}^{+}$content of wax apple fruit increased with NAA treatments. It has been reported in our previous study (KHANDAKER et al. 2012b) that application of growth regulators significantly increased total sugar, carbohydrate, phenol, flavonoid, anthocyanin and carotenoids of wax apple fruits. It was also observed that treated fruits produced higher phenylalanine ammonia lyase (PAL) and antioxidant activity levels. In this study, we investigated the effects of NAA on postharvest storage quality of wax apple fruits. Fruit firmness and weight of wax apple did not changed significantly in storage time. FIGUEROA et al. (2012) also reported that the application of $\mathrm{CaCl}_{2}$ and NAA alone or in combination did not significantly avoid fruit firmness reduction during storage time, suggesting that dips at $45^{\circ} \mathrm{C}$ can be sufficient. However, SUPAPVANICH et al. (2011) reported that firmness of the fresh-cut wax apple remained constant throughout storage. In storage, TSS increased initially and later on decreased gradually in both treated and untreated fruits. The reduction of total soluble solid might be related to the biosynthesis of anthocyanin. This biosynthesis of anthocyanin is induced by sugars such as sucrose, glucose, fructose, or galactose (KHANDAKER et al, 2012b). Slight change in titratable acidity and $\mathrm{pH}$ of wax apple fruits during storage also observed in this study. TEHRANI et al. (2011) also reported similar change of TA and $\mathrm{pH}$ of wax apple fruits in room temperature storage. They also suggested that during storage, fruits utilize organic acids for metabolic activities and these results decrease the TA content during the storage periods. TECCHIO et al. (2009) reported that preharvest application of NAA reduced the incidence of decay of 'Nigara Rosada' grapes in post harvest storage. Our results related to browning index are supported by the results of AL-OBEED (2012) who reported that preharvest NAA application reduced the browning index of Jujube. These may be due to inhibitory effects of NAA on polyphenol oxidase (PPO), which lead to browning (HODGES, 2003).

Wax apple is a non-climacteric fruit and its respiration rate is from 8 to $11 \mathrm{mg} \mathrm{CO}_{2} \mathrm{Kg}^{-1} \mathrm{~h}^{-1}$. Our results showed that the respiration and ethylene production rate and postharvest senescence of wax apple was significantly lower in NAA treated compared to untreated fruits. It has been reported earlier that NAA application at fruit developmental stage decreased the polygalacturonase enzyme activity, which increased the strength of glycosidic bonds and pectin content in cell wall of pedicel and wax apple fruits. Consequently, NAA treatments protect to soften the peel and pulp of mature wax apple fruits and reduced the ethylene production as well as improved pre and postharvest quality of wax apple fruits.

TABLE 1 - Effects of different treatments of NAA on chlorophyll fluorescence, photosynthetic yield, stomatal conductance, DM in leaf and TSS (\% Brix) of wax apple.

\begin{tabular}{|c|c|c|c|c|c|c|c|}
\hline \multirow{2}{*}{ Treatments } & \multirow{2}{*}{$\begin{array}{l}\text { Chlorophyll } \\
\text { (SPAD) }\end{array}$} & \multicolumn{3}{|c|}{ Chlorophyll fluorescence } & \multirow{2}{*}{$\begin{array}{l}\text { Photosynthetic } \\
\text { yield } \mathrm{F}_{\mathrm{v}} \mathrm{F}_{\mathrm{M}}\end{array}$} & \multirow{2}{*}{$\begin{array}{l}\text { c Stomatal } \\
\text { cond. }\left(\mathrm{mmol} \mathrm{m} \mathrm{m}^{-2} \mathrm{~s}^{-}\right.\end{array}$} & \multirow[t]{2}{*}{$\mathrm{DM}$ in leaf } \\
\hline & & $\mathrm{F}_{0}$ & $\mathrm{~F}_{\mathrm{M}}$ & $F_{\mathrm{v}}$ & & & \\
\hline Control & $53.96 \mathrm{c}$ & $419 c$ & $1152 \mathrm{c}$ & $1433 c$ & $0.82 \mathrm{~b}$ & $225 \mathrm{~d}$ & $1.29 \mathrm{c}$ \\
\hline NAA $5 \mathrm{mg} / \mathrm{L}$ & $66.10 \mathrm{~b}$ & $503 b$ & $2044 b$ & $1741 b$ & $0.85 \mathrm{a}$ & $432 \mathrm{c}$ & $1.79 \mathrm{a}$ \\
\hline NAA $10 \mathrm{mg} / \mathrm{L}$ & L $71.76 \mathrm{a}$ & $585 \mathrm{a}$ & $3367 \mathrm{a}$ & $2955 \mathrm{a}$ & $0.84 \mathrm{a}$ & $591 \mathrm{a}$ & $2.24 \mathrm{a}$ \\
\hline NAA $20 \mathrm{mg} / \mathrm{L}$ & L $63.90 \mathrm{~b}$ & $600 \mathrm{a}$ & $1901 \mathrm{a}$ & $2850 \mathrm{a}$ & $0.83 \mathrm{a}$ & $509 \mathrm{~b}$ & $1.34 \mathrm{~b}$ \\
\hline
\end{tabular}

Means ( \pm S.E) within the same column followed by the same letter, do not differ significantly according to LSD test at $\alpha=0.01 \mathrm{~ns}$, nonsignificant* Significant at 0.05 levels, ** Significant at 0.01 levels 
TABLE 2 - Effects of different treatments of NAA on number of buds, bud drop, fruit set, pre harvest fruit dropping and yield of wax apple.

\begin{tabular}{|c|c|c|c|c|c|c|c|}
\hline $\begin{array}{c}\text { Treatments } \\
\left(\mathrm{mg} \mathrm{L}^{-1}\right)\end{array}$ & $\begin{array}{l}\text { Leaf protein } \\
\left(\mathrm{mg} \mathrm{g}^{-1}\right)\end{array}$ & $\begin{array}{l}\text { SPS enzyme } \\
\text { activity }\end{array}$ & $\begin{array}{c}\text { Bud } \\
\text { number }\end{array}$ & $\begin{array}{c}\text { Fruit set } \\
(\%)\end{array}$ & $\begin{array}{l}\text { Fruit drop } \\
(\%)\end{array}$ & $\begin{array}{l}\text { Yield } \\
(\mathrm{kg})\end{array}$ & $\begin{array}{l}\mathrm{K}+\text { content } \\
\left(\mathrm{mg} \mathrm{kg}^{-1}\right)\end{array}$ \\
\hline Control & $5.66 \mathrm{~b}$ & $10.7 \mathrm{~b}$ & $49 c$ & $27 \mathrm{~b}$ & $52 \mathrm{a}$ & $0.31 \mathrm{~b}$ & $15.3 \mathrm{c}$ \\
\hline NAA 5 & $6.16 \mathrm{a}$ & $12.7 \mathrm{a}$ & $62 \mathrm{a}$ & $41 \mathrm{a}$ & $30 c$ & $0.50 \mathrm{a}$ & $67.3 \mathrm{a}$ \\
\hline NAA 10 & $6.87 \mathrm{a}$ & $15.3 \mathrm{a}$ & $57 \mathrm{~b}$ & $46 a$ & $41 b$ & $0.54 \mathrm{a}$ & $76.0 \mathrm{a}$ \\
\hline NAA 20 & $6.65 a$ & $11.6 \mathrm{a}$ & $53 b$ & $47 a$ & $42 \mathrm{~b}$ & $0.42 \mathrm{a}$ & $28.3 \mathrm{~b}$ \\
\hline
\end{tabular}

Means $( \pm$ S.E) within the same column followed by the same letter, do not differ significantly according to LSD test at $\dot{\alpha}=0.01 \mathrm{~ns}$, nonsignificant* Significant at 0.05 levels, ** Significant at 0.01 levels

TABLE 3- Effects of different treatments of NAA on postharvest qualities of wax apple fruits at control atmosphere storage

\begin{tabular}{cccccc}
\hline Parameter & Treatment & & & \multicolumn{2}{c}{ Storage time (day) } \\
& $\left(\right.$ mg L $\left.^{-1}\right)$ & 0 & 5 & 10 & 15 \\
\hline \multirow{4}{*}{ Firmness } & Control & $7.0 \mathrm{~b}$ & $6.1 \mathrm{~b}$ & $5.0 \mathrm{~b}$ & $4.3 \mathrm{~b}$ \\
& NAA 5 & $7.3 \mathrm{a}$ & $6.8 \mathrm{a}$ & $6.3 \mathrm{a}$ & $5.8 \mathrm{a}$ \\
& NAA 10 & $7.8 \mathrm{a}$ & $7.0 \mathrm{a}$ & $6.4 \mathrm{a}$ & $5.9 \mathrm{a}$ \\
& NAA 20 & $7.7 \mathrm{a}$ & $6.6 \mathrm{a}$ & $6.0 \mathrm{a}$ & $5.4 \mathrm{a}$ \\
Weight loss (\%) $)$ & Control & 0.0 & $2.0 \mathrm{a}$ & $5.0 \mathrm{a}$ & $15 \mathrm{a}$ \\
& NAA 5 & 0.0 & $1.8 \mathrm{~b}$ & $4.7 \mathrm{~b}$ & $12 \mathrm{~b}$ \\
& NAA 10 & 0.0 & $1.7 \mathrm{~b}$ & $4.8 \mathrm{~b}$ & $10 \mathrm{~b}$ \\
TSS $\left({ }^{\circ}\right.$ Brix $)$ & NAA 20 & 0.0 & $1.6 \mathrm{~b}$ & $4.6 \mathrm{~b}$ & $11 \mathrm{~b}$ \\
& Control & $6.70 \mathrm{c}$ & $7.00 \mathrm{~b}$ & $6.98 \mathrm{c}$ & $6.2 \mathrm{~b}$ \\
& NAA 5 & $9.40 \mathrm{~b}$ & $10.5 \mathrm{a}$ & $9.80 \mathrm{~b}$ & $8.5 \mathrm{a}$ \\
& NAA 10 & $10.7 \mathrm{a}$ & $11.5 \mathrm{a}$ & $10.9 \mathrm{a}$ & $9.6 \mathrm{a}$ \\
TA $(\%$ Citric & NAA 20 & $9.66 \mathrm{~b}$ & $10.3 \mathrm{a}$ & $10.4 \mathrm{~b}$ & $9.4 \mathrm{a}$ \\
acid) & Control & $0.78 \mathrm{a}$ & $0.76 \mathrm{a}$ & $0.75 \mathrm{a}$ & $0.74 \mathrm{a}$ \\
& NAA 5 & $0.73 \mathrm{~b}$ & $0.77 \mathrm{~b}$ & $0.72 \mathrm{~b}$ & $0.70 \mathrm{~b}$ \\
& NAA 10 & $0.72 \mathrm{~b}$ & $0.74 \mathrm{~b}$ & $0.72 \mathrm{~b}$ & $0.63 \mathrm{~b}$ \\
pH & NAA 20 & $0.71 \mathrm{~b}$ & $0.73 \mathrm{~b}$ & $0.71 \mathrm{~b}$ & $0.63 \mathrm{~b}$ \\
& Control & $4.92 \mathrm{a}$ & $4.93 \mathrm{a}$ & $4.90 \mathrm{a}$ & $4.88 \mathrm{a}$ \\
& NAA 5 & $4.95 \mathrm{a}$ & $5.01 \mathrm{a}$ & $5.00 \mathrm{a}$ & $5.03 \mathrm{a}$ \\
& NAA 10 & $5.12 \mathrm{a}$ & $5.22 \mathrm{a}$ & $5.18 \mathrm{a}$ & $5.16 \mathrm{a}$ \\
Browning index & NAA 20 & $5.09 \mathrm{a}$ & $5.20 \mathrm{a}$ & $5.18 \mathrm{a}$ & $5.15 \mathrm{a}$ \\
& Control & $0.4 \mathrm{a}$ & $1.2 \mathrm{a}$ & $3.2 \mathrm{a}$ & $5.2 \mathrm{a}$ \\
& NAA 5 & $0.2 \mathrm{~b}$ & $0.8 \mathrm{~b}$ & $2.0 \mathrm{~b}$ & $3.7 \mathrm{~b}$ \\
& NAA 10 & $0.1 \mathrm{~b}$ & $0.7 \mathrm{~b}$ & $1.9 \mathrm{~b}$ & $3.9 \mathrm{~b}$ \\
& NAA 20 & $0.1 \mathrm{~b}$ & $0.7 \mathrm{~b}$ & $2.3 \mathrm{~b}$ & $4.0 \mathrm{~b}$ \\
\hline
\end{tabular}

Means $( \pm$ S.E) within the same column followed by the same letter, do not differ significantly according to LSD test at $\dot{\alpha}=0.01 \mathrm{~ns}$, nonsignificant * Significant at 0.05 levels, $* *$ Significant at 0.01 level 


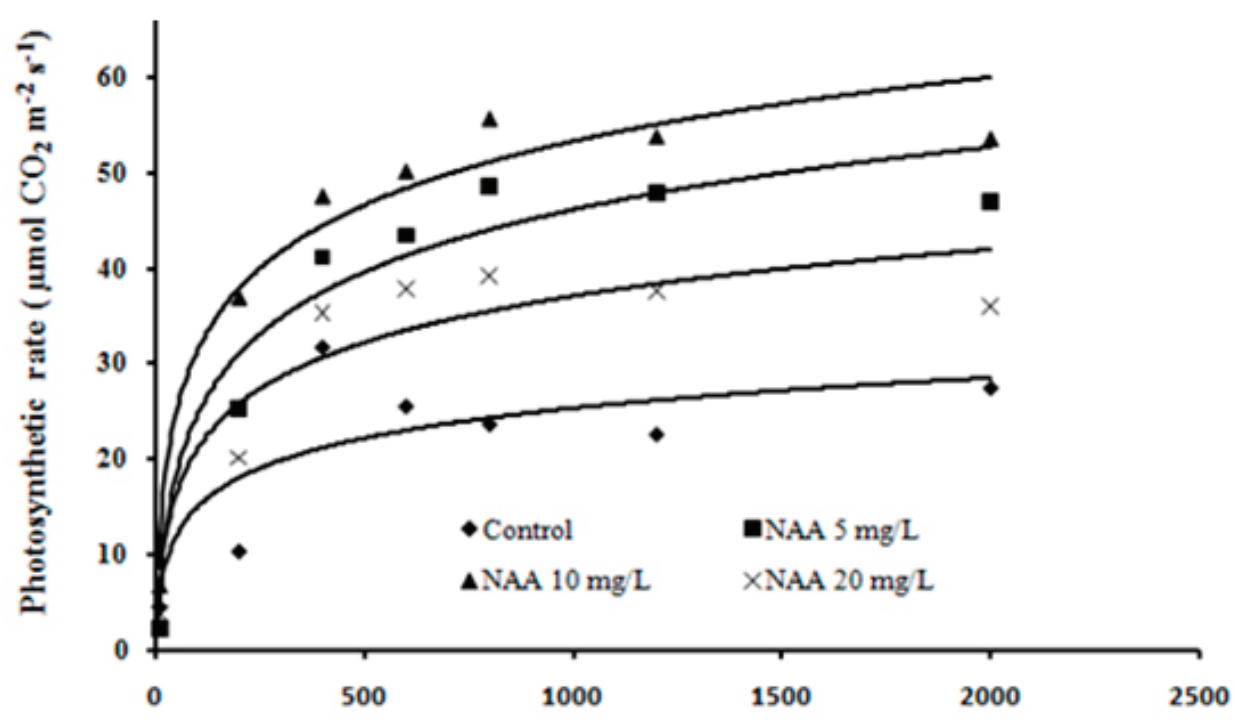

Photosynthetic Active Radiance $\left(\mu \mathrm{mol} \mathrm{m} \mathrm{m}^{-2} \mathrm{~s}^{-1}\right)$

FIGURE 1- Effects of NAA treatments on net photosynthetic rate of wax apple trees under field condition $(n=12)$. Data were recorded at one week after fruit set.

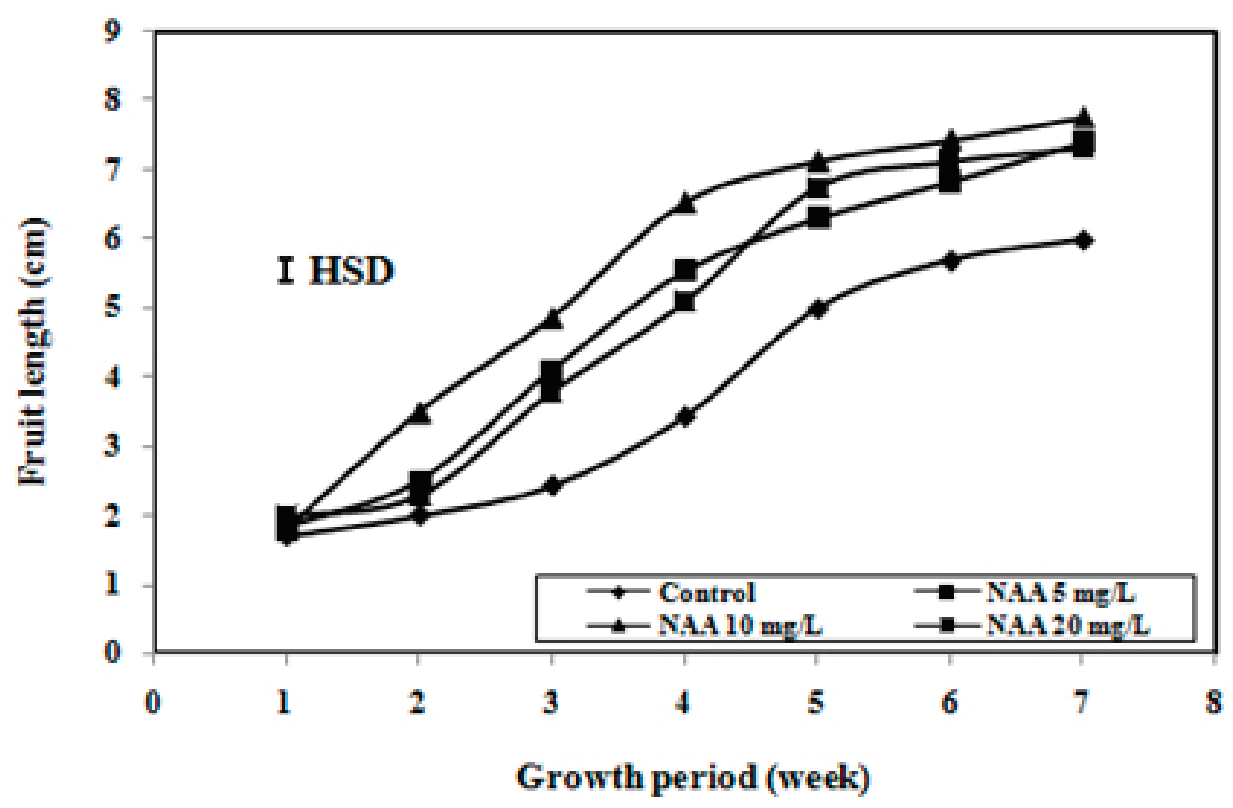

FIGURE 2-The effects of different treatments of NAA on fruit growth length $(\mathrm{cm})$ of wax apple under field condition. 


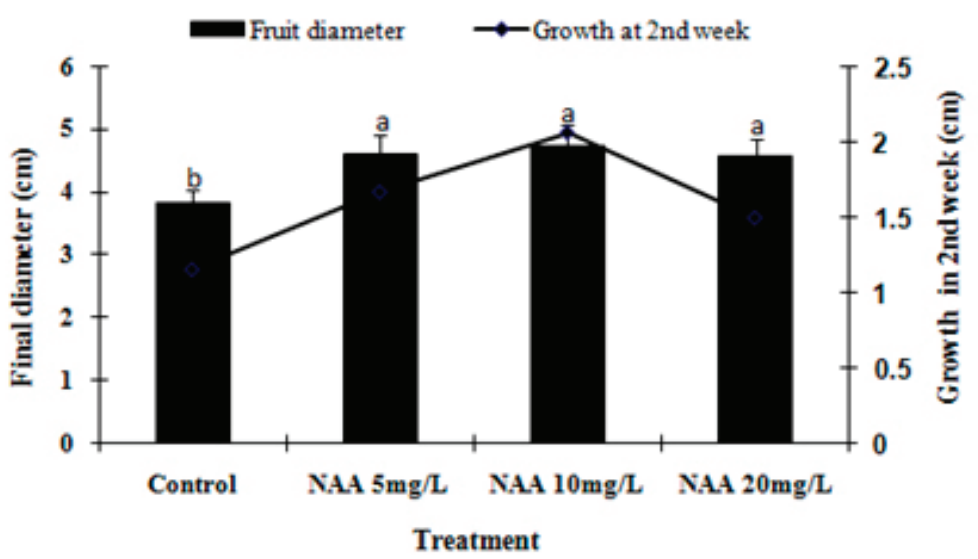

FIGURE 3-Final fruit diameter (cm) and fruit growth of wax apple at 2nd

week asaffected by different treatments of NAA. Bars indicate \pm S.E. and values $(n=12)$ followed by the same letter were not significantly different at $\mathrm{p}<0.05$.

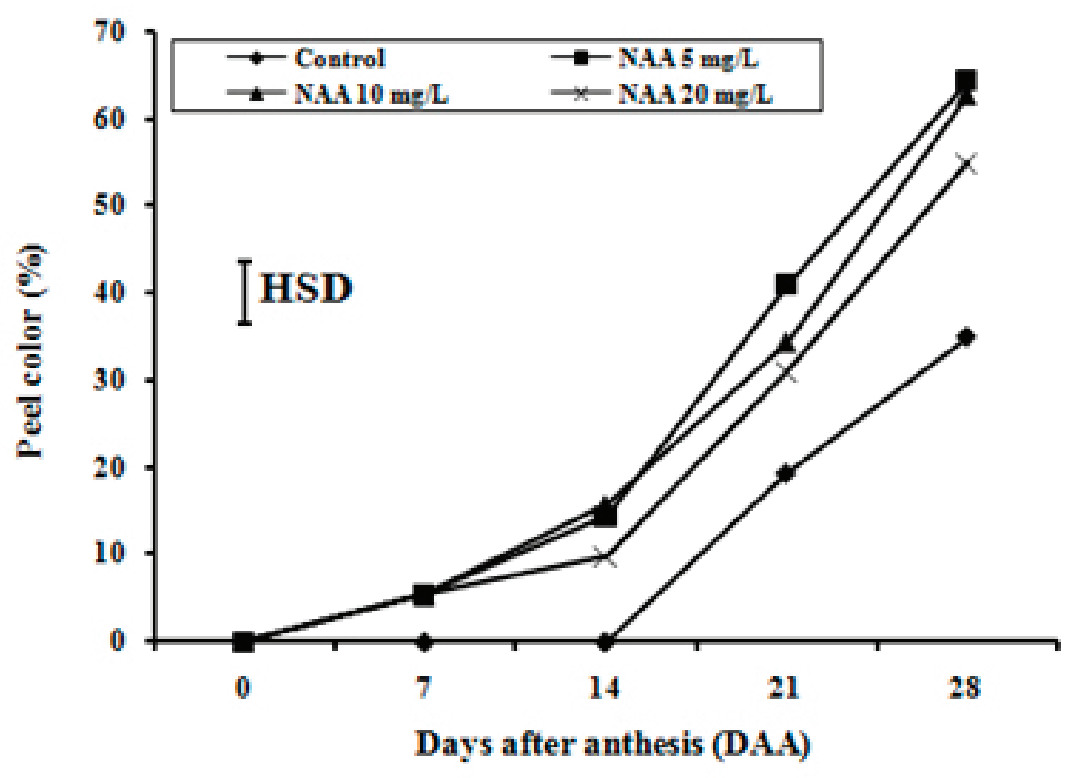

FIGURE 4- The effect of NAA treatments on color development (\%) of wax apple fruit after anthesis $(n=12)$. 


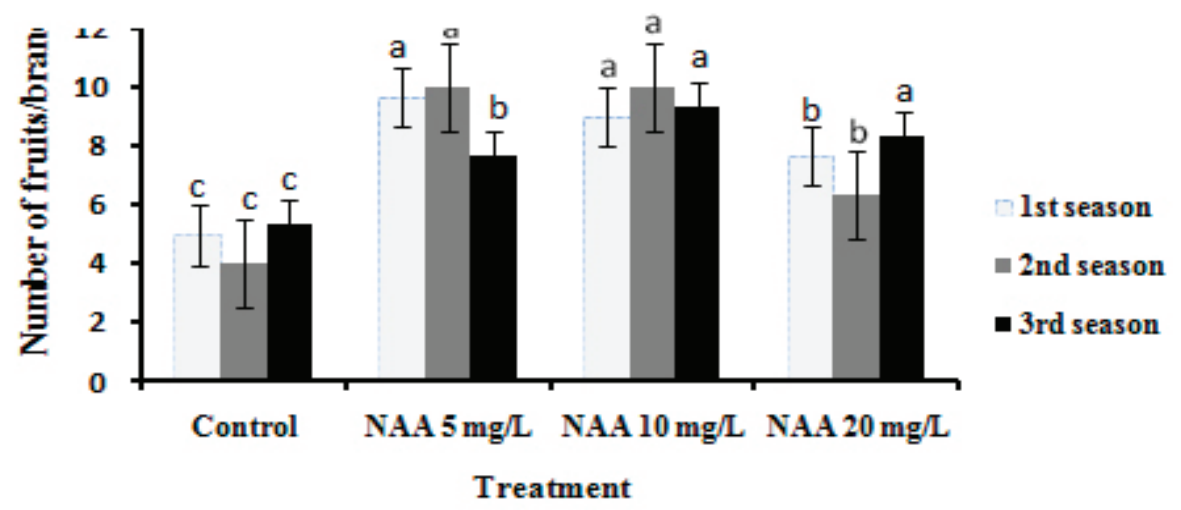

FIGURE 5- The effects of NAA treatments on total number of fruits in wax apple through out the three growing seasons. Bars indicate \pm S.E. and values $(n=30)$ followed by the same letter were not significantly different at $\mathrm{p}<0.05$ (LSD test).

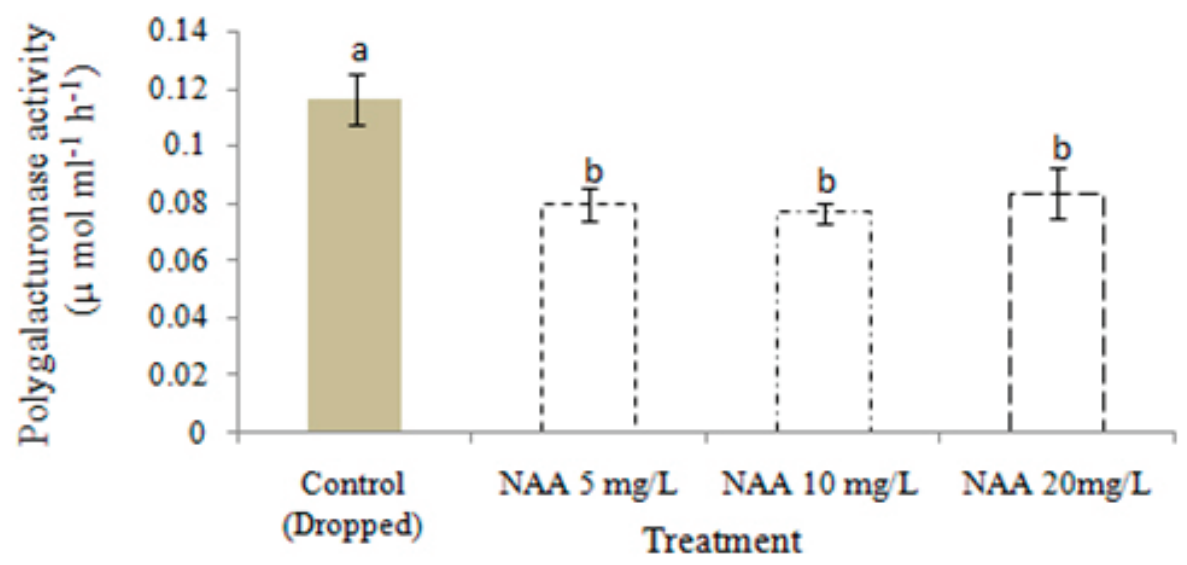

FIGURE 6- The effect of NAA treatments on polygalacturonase activity of wax apple fruits. Dropped fruit used as a control treatment. Bars indicate $\pm \mathrm{S}$. E.

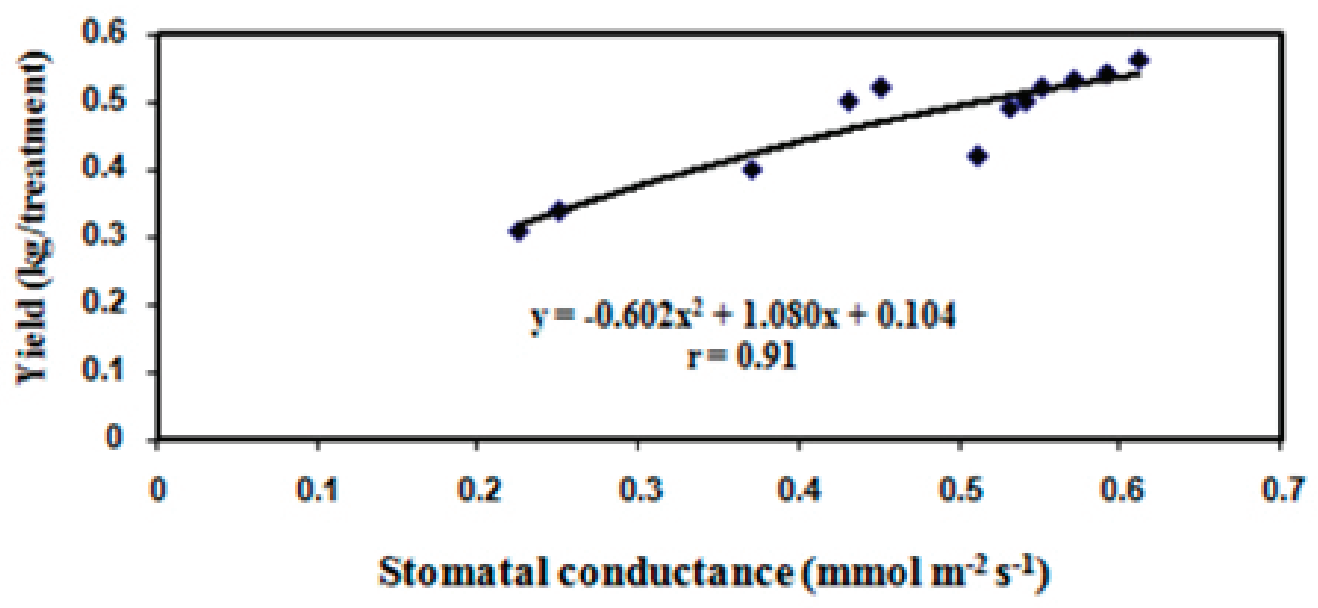

FIGURE 7-Correlation between stomatal conductance and yield of wax apple fruits as affected by NAA treatments. 


\section{CONCLUSIONS}

From the above results, it can be concluded that tested concentrations of NAA particularly 5 and $10 \mathrm{mg} \mathrm{L}^{-1}$ NAA can improve the growth, yield and postharvest quality of wax apple fruit. Treatment with $10 \mathrm{mg} \mathrm{L}^{-1} \mathrm{NAA}$ gave promising results with respect to plant physiological properties; leaf chlorophyll content, net photosynthesis rate, stomatal conductance and chlorophyll fluorescence and enhanced faster fruit growth and color development. Additionally, $5 \mathrm{mg} \mathrm{L}^{-1} \mathrm{NAA}$ treatment improved fruit set and reduced fruit drop and polygalacturonase activity. Treatment with $10 \mathrm{mg} \mathrm{L}^{-1}$ NAA increased fruit yield, dry matter, $\mathrm{K}^{+}$and TSS content in the fruits. Our results also showed that NAA-treated plant exhibited a positive correlation between stomatal conductance and fruit yield. NAA treatedfruits exhibited low respiration rate and ethylene production and highest post harvest quality in 15 days of cold storage. We concluded that 5 and 10 $\mathrm{mg} \mathrm{L}^{-1} \mathrm{NAA}$ treatments are promising concentration for enhancing the growth, development and yield under field conditions and improving the post harvest quality of wax apple fruits.

\section{ACKNOWLEDGEMENT}

This research was financially supported by University of Malaya, Kuala Lumpur, 50603,Malaysia (Project No.RG002/09BIO) and University of Sultan Zainal Abidin, Tembila Campus, 22200 Besut, Terengganu, Malaysia (Project No.UniSZA/14/ GU/024).

\section{REFERENCES}

AGUSTI, M.; El-OTMANI, M.; JUNE, M.; ALMELA, V. Effect of 3, 5, 6-trichloro-2pyridyloxyacetic acid on Clementine early fruitlet development and on fruit size at maturity. Journal of Horticultural Science, Ashford, v.70, p.955-962, 1995.

ALMESELMANI, M.; PANT R. C.; SINGH, B. Potassium Level and Physiological Response and Fruit Quality in Hydroponically Grown Tomato. International Journal of Vegetable Science, New York, v.16, p.85-99, 2010.

Al-OBEED, R.S. Jujube post-harvest fruit quality and storagability in response to agro-chemicals preharvest application. African Journal of Agricultural Research, Nairobi, v.7, p.5099-5107. 2012.
AMOROS, A.; ZAPATA, P.; PRETEL, M. T.; BOTELLA, M. A.; ALMANSA M. S.; SERRANO, M. Role of Naphthalene Acetic Acid and phenothiol treatments on increasing fruit size and advancing fruit maturity in loquat. Scientia Horticulturae, Amsterdam, v.101, p.387-398, 2003.

BHATTARAI, D. R.; GAUTAM, D. M. Effect of harvesting method and calcium on post harvest physiology of tomato. Nepal Agricultural Research Journal, Kathmandu, v.7, p.37-41, 2006.

BHOWMIK, P.K.; TAMURA, K.; SANADA, Y.; TASE, K.; YAMADA, T. Sucrose metabolism of perennial ryegrass in relation to cold acclimation. Zeitschrift für Naturforschung C, Tubingen, v.61,p.99-104, 2006.

CZERPAK, R.P.; DOBRZYN, A.; KROTKE, E.; KICINSKA. The Effect of Auxins and Salicylic Acid on Chlorophyll and Carotenoid Contentsin Wolffia Arrhiza (L.) Growing on Media of Various Trophicities. Polish Journal of Environmental Studies, Osztyn, v.11, p.231-235, 2002.

DAVIES, F. S.; ZALMAN, G. Gibberellic acid, fruit freezing, and post-freeze quality of Hamlin oranges. HortTechnology, Alexandria, v.16, p.301-305, 2006.

DUTTA, P.; BANIK, A. K. Effect of foliar feeding of nutrients and plant growth regulators on physicochemical quality of Sardar guava grown in West Bengal. Acta Horticulturae, The Hague, v.335 p.407-411, 2007.

FIGUEROA, C. R.; OPAZO, M.C.; VERA, P.; ARRIAGADA, O.; DIAZ, M. M.; MOYA-LEON, A. Effect of postharvest treatment of calcium and auxin on cell wall composition and expression of cell wall-modifying genes in the Chilean strawberry (Fragaria chiloensis) fruit. Food Chemistry, Berlin, v.132, p.2014-2022, 2012.

GUTAM, S.; KOTI, R.V.; CHETTI, M. B.; HIREMATH, S. M. Effect of NAA and Mepiquat chloride on physiological components of yield. Journal of Agricultural Research, Washington, v.47, p.210-216, 2009.

HODGES, D. M. Postharvest oxidative stress in horticultural crops. New York: Food Products Press, 2003. 
IERSEL, M. C. Auxin applications affect post transplant $\mathrm{CO}_{2}$ exchange rate and growth of bare rooted Vinca [Catharanthus roseus (L.) G. Don] Seedlings. Journal of the American Society of Horticultural Science, Alexandria, v.124, p.234238, 1999.

IQBAL, M.; KHAN, M. Q.; JALAL, U. D.; REHMAN, K.; MUNIR, M. Effect of foliar application of NAA on fruit drop, yield and physicochemical characteristics of guava (Psidium guajava L.) Red flesh cultivar. Journal of Agricultural Research, Washington, v.47, p.259-269, 2009.

JONG, M. de; MARIANI, C.; VRIEZEN, W. H.The role of auxin and gibberellin in tomato fruit set. Journal of Experimental Botany, Lancaster, v.60, p.1523-1532, 2009. (1) Arrumar na p. 8 linha 27 de MAAIKE et al. (2009) para JONG et al. 2009

KHANDAKER, M. M.; BOYCE, A. N.; OSMAN, N. The influence of hydrogen peroxide on the growth, development and quality of wax apple (Syzygium samarangense, [Blume] Merrill \& L.M. Perry var. jambu madu) fruits. Plant Physiology and Biochemistry, Paris, v.53, p.101-110, 2012a.

KHANDAKER, M. M.; BOYCE, A. N.; OSMAN, N.; GOLAM, F.; RAHMAN,M.M.; SOFIANAZIRUN, M. Fruit Development, Pigmentation and Biochemical Properties of Wax Apple as Affected by Localized Application of $\mathrm{GA}_{3}$ under Field Conditions. Brazilian Archives of Biology and Technology, Curitiba, v. 56, n.1, p.11-20, 2013.

KHANDAKER, M. M.; BOYCE, A. N.; OSMAN, N.; HOSSAIN, A. B. M. S Physiochemical and Phytochemical Properties of Wax Apple (Syzygium samarangense [Blume] Merrill \& L. M. Perry var. Jambu Madu) as Affected by Growth Regulator Application. The Scientific World Journal, Nasr City, v.2012, p.13, 2012b.

KHANDAKER, M.M.; HOSSAIN A.S.; OSMAN N.; BOYCE, A.N. Application of girdling for improved fruit retention, yield and fruit quality in Syzygium samarangense under field conditions. International Journal of Agriculture and Biology, Faisalabad, v.13, p.18-24, 2011.
KHANDAKER,M. M.; HOSSAIN, A. B. M. S., SANI, W.; SAIFUDDIN, M.; ALENAZI, M. Effect of harvesting and storage conditions on the post harvest quality of tomato (Lycopersicon esculentum Mill) cv. Roma VF. Australian Journal of Crop Science, Melbourne, v. 3, p.113-121, 2009.

KOLER, P., PATIL, B. C.; CHETTI, M. B.; HIREMATH, S. M. Influence of plant growth regulators on total dry matter, leaf area index and yield, yield components in hybrid cotton. Karnataka Journal of Agricultural Science, Dharwad, v.23, p.503-505, 2008.

LU, Z. M.; PERCY, R. G.; QUALSET C. O.; ZEIGER, E. Stomatal conductance predicts yields in irrigated Pima cotton and bread wheat grown at high temperatures. Journal of Experimental Botany, Lancaster, v.49, p.453-460, 1998.

MILLER, A. N.; WALSH, C. S.; COHEN, J. D. Measurement of indole-3-acetic acid in peach fruits (Prunus persica L. Batch cv. Red haven) during development. Plant Physiology, Chicago, v.84, p.491-494, 1987.

MONERUZZAMAN, K. M.; ALEBIDI, A. I.; Al-SAIF, A.M. Assessment of genetic diversity in three cultivars of Syzygium samarangense growth in Malaysia by using morphological and physiological parameters, Research Journal of Biotechnology, New York, v.7, n.3, p.1-7. 2012.

MORTON, J. Java apple. In: MORTON, J. Fruits of warm climates. Winterville: Criative Resource System, 1987. p.381-382.

NAHAR, S. B.; TAKESHI, I. Effect of different concentrations of Figaron on production and abscission of reproductive organs, growth and yield of soybean. Field Crop Research, Amsterdam, v.78, p.41-50, 2002.

RODRIGUES, Alessandro et al. $\mathrm{GA}_{3}$ and CPPU application on 'Itália' grapes grown in Porto FelizSP. Revista Brasileira de Fruticultura, Jaboticabal, v.33, n.1, p.1-7, 2011.

SERRANI, J. C.; RUIZ-RIVERO, O.; FOS, M.; José Luis GARCIA-MARTINEZ, J.L.; Auxin-induced fruit-set in tomato is mediated in part by gibberellins. The Plant Journal, Oxford, v. 56, p.922-34, 2008. 
SUPAPVANICH, S.; PIMSAGA, J.; SRISUJAN

P. Physicochemical changes in fresh-cut wax apple (Syzygium samarangenese [Blume] Merrill \& L.M. Perry) during storage. Food Chemistry, Berlin, v.127, p.912-917, 2011.

TECCHIO, M. A. et al. Effect of naphthalene acetic acid and calcium chloride in reducing postharvest losses of 'Nigara Rosada' grapes. Revista Brasileira de Fruticultura, Jaboticabal, v.31, n.1, p. 53-61, 2009.
TEHRANI, M.; CHANDRAN, S.; HOSSAIN, A. B. M. S.; BOYCE, A. N. Postharvest physico-chemical and mechanical changes in jambu air (Syzygium aqueum Alston) Fruits. Australian Journal of Crop Science, Melbourne, v.5, p.32-38, 2011.

TU, K.; NICOLAI, B.; BAERDEMAEKER, J. D. Effects of relative humidity on apple quality under simulated shelf temperature storage. Scientia Horticulturae, Amsterdam, v.85, p.217-229, 2000.

ZEN-HONG, S.; MEON, Z.; TIRTAWINATA, R.; THANARUT, C. Wax apple production in selected tropical Asian countries. ISHS, Acta Horticulturae, The Hague, v.773, p.161-164, 2006. 